\title{
STUDY ON BALE BALE IN LAE LAE ISLE, MAKASSAR, INDONESIA インドネシア・マカッサルのラエラエ島に㧍ける「バレバレ」に関する研究
}

\author{
Abdul Mufti RADJA*, Takeshi SUZUKI**, Yuko YOSHIZUMI***, \\ Mariko KOUSAKA ${ }^{* * * *}$, Kiyoshi YAMAUCHI ${ }^{* * * *}$, Shigeki MATSUBARA **** \\ and Toshinobu $O K U^{* * * * * *}$ \\ アブドゥムフティラジャ, 鈴 木 毅, 吉 住 優子, 向阪 真理子 \\ 山内清史，松原茂樹，奥＼cjkstart俊信
}

\begin{abstract}
This study aims to examine the types and characteristics of Bale bale, and to identify Bale bale as a common space in a high-density environment on Lae Lae isle, Makassar-Indonesia. With the aid of 62 questionnaires, a field survey of 225 Bale bale was undertaken in November 2009 and September 2010. The following are the main findings of this study: (1) The owner can put their Bale bales anywhere on Lae Lae isle and they can move their Bale bales from one place to another, including neighbors without permission. (2) Bale bale is classified into five types, namely, siring; terrace, yard, roadside, and seashore. (3) The Bale bale takes either of two forms: prototype and hut shaped. (4) The direction of the Bale bale prototype is either one way, facing the street, inside, and on the house's sides. The direction of the hut-shaped Bale bale is toward the house, toward the street, and toward the sea. (5) The roadside Bale bale is used more often than the other types. Sitting and chatting are the most frequent activities performed by islanders on the Bale bale. Sleeping, eating, , and repairing boat machines are mostly done by Lae Lae islanders on roadside and seashore Bale bales.
\end{abstract}

Keywords: Indonesia, Makassar, Lae Lae isle, Bale bale, Street Furniture インドネシア, マカッサル, ラエラエ島, バレバレ, ストリートファニチャー

\section{Introduction}

Bale bale $^{(\mathrm{i})}$ is a gathering space found in Lae Lae isle, either at home or in public space, in breakwater, under trees, and along the ring road of the isle (fig. 1). According to an Indonesian dictionary (2008), "Bale bale or balai balai is a seat or a bed, made of bamboo or wood." Bale bale is simply constructed and moveable; it can be moved by its owner, or by neighbors wherever they want. It has a variety of forms and sizes, in addition to the simple and small bench-like ones. We also found many large Bale bale with tents along ring roads. Islanders own not just one Bale bale but two or three Bale bales, which are placed around their house.

All generations, including babies, children, young men, elderly people, males, and females often use Bale bales for

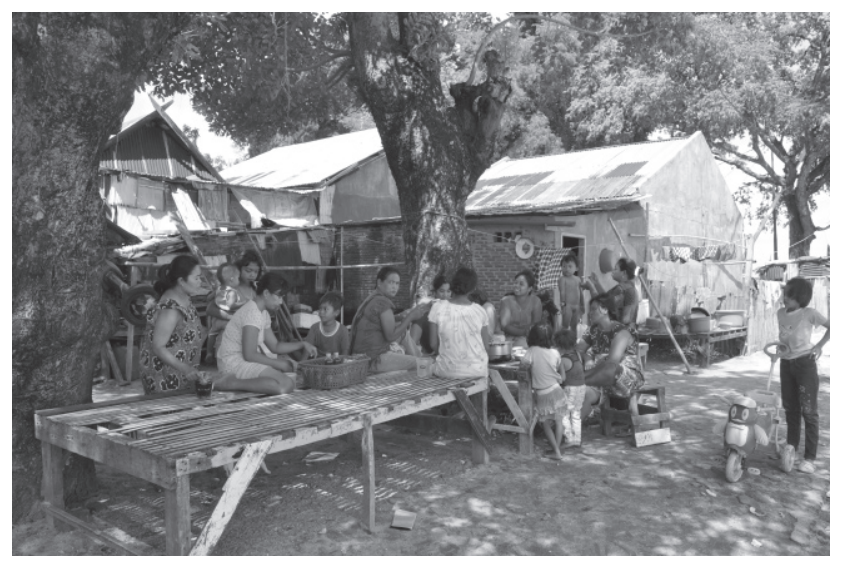

Fig. 1 Bale bale in a public space

various activities trough out the day. These activities include
* Grad. Student, Dept. of Global Architecture, Graduate School of Engineering, Osaka University

** Assoc. Prof., Dept. of Global Architecture, Graduate School of Engineering, Osaka University, Dr. Eng.

*** Researcher, Dept. of Global Architecture, Graduate School of Engineering, Osaka University, Dr. Eng.

**** Grad. Student, Dept. of Global Architecture, Graduate School of Engineering, Osaka University

***** Assist. Prof., Dept. of Global Architecture, Graduate School of Engineering, Osaka University, Dr. Eng.

****** Prof., Dept. of Global Architecture, Graduate School of Engineering, Osaka University, Dr. Eng.
大阪大学大学院工学研究科地球総合工学専攻 博士課程

大阪大学大学院工学研究科地球総合工学専攻 准教授

大阪大学大学院工学研究科地球総合工学専攻 特任研究員

大阪大学大学院工学研究科地球総合工学専攻 修士課程

大阪大学大学院工学研究科地球総合工学専攻 助教

大阪大学大学院工学研究科地球総合工学専攻 教授 


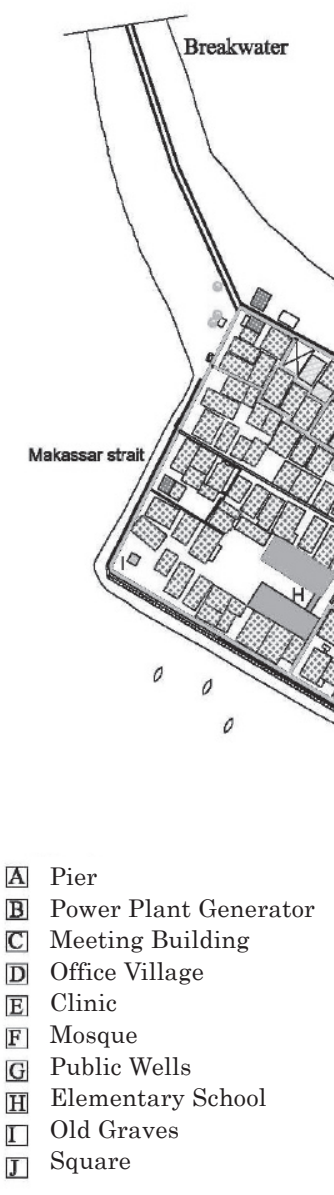

RW 3

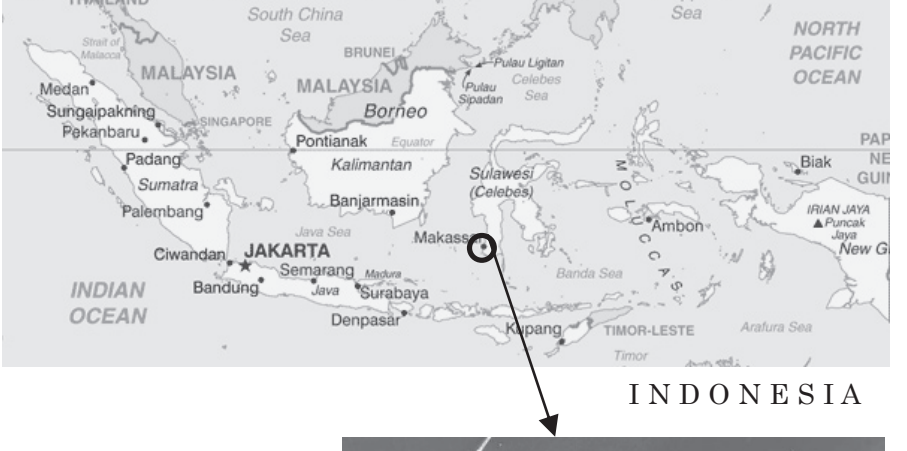

RW 2

Sea

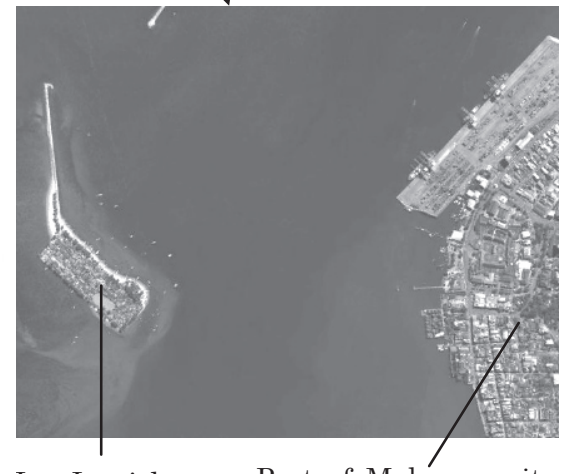

\%ख Landed House

$\square$ House in Stilts (RP)

……1 Kiosk

8. House with Kiosk

$\square$ Small Restaurant

$\bowtie$ Empty Land

$\simeq$ Ring road, Alley

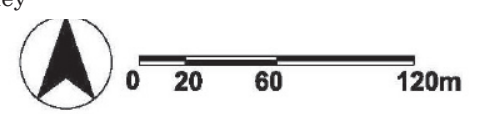

Fig. 2 Location of field survey

gathering, sitting, sleeping, lying down, eating, drinking, and chatting. People use not only their own Bale bale, but also those of neighbors and visitors from outside the island. By custom, it is not necessary to ask for permission to use another's Bale bale.

Bale bales are designed not only for use by many people, but also for a single person to sit on and to participate in other activities. Bale bale becomes a social gathering place when other people arrive; they greet one another, some sit, and some stand around while they all eat (Gehl, 1987). A similar scene at Sinlong Park in Taipei is described by Suzuki (1997), where all generations perform a variety of social activities..

Many studies have been conducted on public spaces as gathering spaces. Noguchi and Tsukidate (2002) reveal that Gangi, a kind of linked corridor which connects many buildings, in northern Japan, are not only used as a passage on the public apartment houses but all types are used in the same way; to "chat with neighbors" and "for children to play." Further, the Gangi are also used as places for residents to socialize and to meet, regardless of weather conditions, be it sunny, rainy, cold, or snowing. Another study conducted by Kanazawa and Jun (2002) indicates that outdoor spaces in both residential on traditional block and a new housing project in Beijing as essential places for the residents' daily and communal lives and a wide variety of activities take place there. Outdoor spaces complement the indoor spaces of housing and offer residents various opportunities to conduct their daily lives with their families and neighbors. Kamihogi, Ujihara, Kajihara, Misawa, and Masuda (2000) conducted a study on the role of common spaces in creating community in exclusive low-rise residential areas. They revealed that common spaces created initial opportunities for being friendly with neighbors, but the frequency of use of common spaces decreased as children in the residential area became older. This indicates that common space is more commonly used by children than by other generations. Cho and Sawaki (2007) reveal that all common spaces in housing environment amelioration programs encompassing the hillside high-density area in Busan, Korea, were located on and around roads. These common spaces are freely utilized as multi-usage space without any prohibition on their usage.

In the abovementioned study, all public spaces are described as large spaces that are a permanent part of the buildings to which they belong. The present study is regarding a small, moveable seating that could be placed anywhere in or around the owner's house and in public spaces, called Bale bale. The purpose of this study is to identify the types and characteristics of Bale 
bales and the activity on Bale bales as a common seating space in Lae Lae isle in Indonesia.

\section{Field Survey and Method}

A field survey was conducted in Lae Lae isle, $12.5 \mathrm{~km}$ from Makassar-Indonesia (fig.2). Lae Lae isle is a high-density environment where a $0.22 \mathrm{~km}^{2}$ area is occupied by 1.563 people, including 793 males and 770 females (Makassar in Figure, 2010). The population comprises both Makassarese and Buginese people and a majority of them are Moslem. Generally, their main livelihood is fishing, although some men ferry passengers by boat from Makassar to Lae Lae isle or other surrounding islands and others work in Makassar. Lae Lae isle is a ward of Lae Lae and it is part of the sub districts of Ujung Pandang; it is divided into three neighborhood-organizations, called Rukun Warga (RW). There are 331 residential houses, which include 256 landed houses and 75 houses on stilts (called Rumah panggung(ii) or RP). Many landed houses are in RW 2 and RW 3, and built of stone and wood materials. Meanwhile, many houses in RW 1 are constructed on stilts because the majority of Buginese people, who are experts in building houses on stilts, live in this zone (fig. 2). There are six public facilities, namely, the office ward of Lae Lae isle, clinic, mosques at the isle's center, an elementary school, public wells, and a power plant that operates from 18:00-24:00.

Data from field surveys were collected in November 2009 and September 2010. The method of field survey included the mapping of the Bale bale's locations, observing users' behaviors, measuring of Bale bales, documenting of users' activities by camera, and interviewing the owners and users of Bale bales. Sixty-two questionnaires were distributed to owners and users of Bale bales before undertaking the field survey in October 2009. The questionnaires were designed to answer the following questions: the purpose of the Bale bale, the social function of Bale bales, the reasons for using Bale bales, and who usually uses the Bale bale.

Users' activities on the Bale bale were analyzed on the basis of the photos, which were taken on three days in September 2010 at three different times: 10:00-12:00, 13:00-15:00, and 15:00-17:00. Furthermore, photos that were taken at the same Bale bales were collected and analyzed with regard to their positions and activities.

\section{Result}

The field surveys revealed that there were 225 Bale bales, located in houses, along the ring road, in alleys, and in public spaces. Some Bale bales have been made by islanders and some have been bought by them from outside the isle. Bale bales can also be easily moved from one place to another due to their shape and lightness. Moreover, owners can put their Bale bales anywhere there is a public space in Lae Lae isle. Some residents ask the permission of the head of the ward of Lae Lae to place large Bale bales in public spaces. Further, some islanders make Bale bales for local tourists who rent them for relaxation purposes; these Bale bales are placed at breakwaters. Others are close to old graves. Islanders also make Bale bales by self-help for other uses, for example, as a place for night watchmen on the isle, which serves as a security post to protect the environment; such Bale bales are located at the center of the isle.

\subsection{Types of Bale bale}

The field surveys revealed that Bale bales in Lae Lae isle can be divided into five types: siring(iii), terrace, yard, roadside, and seashore (fig. 3). The roadside Bale bale type is in the majority and the siring type is in the minority in this isle (fig. 4). Many Bale bales are located along the ring road, around the coast, and in the alleys. Some Bale bales are placed in front of shops located on the ring road and in front of public wells. Fig. 5 presents the location of all Bale bales on the isle, with $55.1 \%$ of Bale bales being located in the coastal area and $44.9 \%$ located on the inner part of the isle.

Type-Sr (Siring)
This type of Bale bale is located
at the $1^{\text {st }}$ and $2^{\text {nd }}$ column
arrangements underneath the
Rumah Panggung.
(21/225)
Type-T (Terrace)
This Bale bale is located on the
terrace of its owner's house.
(59/225)
Type-Y (Yard)
The "Y" type of Bale bale is
located around or inside the
fence of the owner's house.
(33/225)
Type-R (Roadside)
This type of Bale bale is located
along the ring road and alley.
(76/225)
Type-Ss (Seashore)
in the coastal area of Lae Lae
isle.
(36/225)

Fig. 3 Type of Bale bale 


\subsubsection{Siring Type}

This type of Bale bale is located at the $1^{\text {st }}$ and $2^{\text {nd }}$ column arrangements underneath the $R P$. There are 21 Bale bales of the "Sr" type (9\%), of which 15 Bale bales are placed in RW 1, 3 Bale bales are placed in RW 2, and three Bale bales are placed in RW 3. A majority of the Bale bales are placed in RW 1 because there are many $R P$ in this area.

In general, the form of the siring Bale bales is the prototype of the Bale bales and does not require a tent because the siring area is protected from the sun. Some islanders use the space underneath the Bale bale as a cage for keeping their chickens. The Bale bale is made of bamboo or wood, and some Bale bales use a combination of the two materials.

\subsubsection{Terrace Type}

There are 59 Bale bales of the "T" type (11\%), 34 of which (58\%) are located on the inner part of the isle and $25(42 \%)$ in the coastal area. Of these 59 Bale bales, five are placed in front of owners' kiosks; the owner can watch people who want to buy something while sitting on his or her Bale bale.

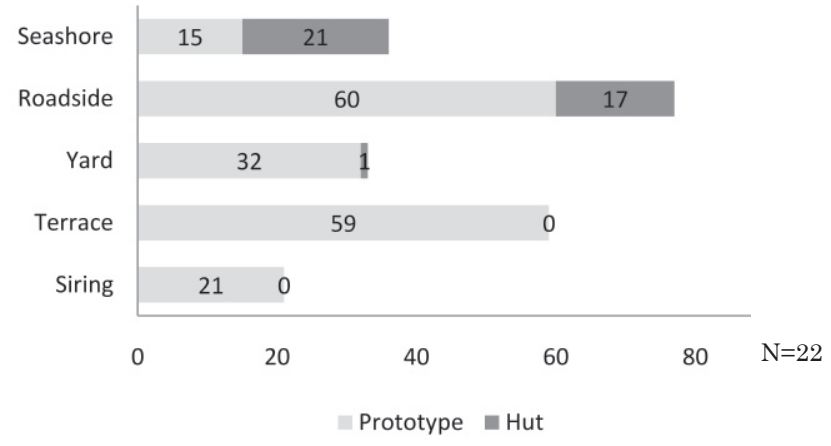

Fig. 4 Number of each types of Bale bale
Similar to the siring type of Bale bale, the "T" type of Bale bale, which is the prototype of Bale bale, is made of either bamboo or wood or only of wood for its main structure and bamboo for its seat.

\subsubsection{Yard Type}

The "Y" Bale bale is located around or inside the the owner's house fence. There are 33 Bale bales of the "Y" type (14.7\%), 19 of which are placed on the inner part of the isle (57.6\%) and 14 are placed along the ring road (42.4\%). In terms of the RW zoning, we found that 15 Bale bales are placed in RW 2, and 9 are placed in RW 1 and RW 3. Most of the Bale bales are in RW 2 because this zone is a densely populated area, with many houses. There are fewer Bale bales in RW 1 because many Bale bales are located within the siring of $R P$.

The "Y" Bale bale has two forms: a prototype, and hut-shaped. These are made of bamboo or wood, or a combination of the two materials and the tent is made of zinc and the leaf of the sago palm. Two Bale bales are located inside the hut and another one uses a temporary plastic tent for protecting users from the elements of nature.

\subsubsection{Roadside}

There are 77 Bale bales of the "R" type (34.2\%), of which 43 are placed along the ring road (55.8\%) and 34 are placed on the inner part of the isle $(45.2 \%)$. The layout of this type of Bale bale implies that it is placed almost in front of the owner's house. The roadside type includes two forms, namely, the prototype of the Bale bale (77.9\%) and the hut-shaped Bale bale (22.1\%).

\subsubsection{Seashore Types}

The "Ss" type of Bale bale is located in the coastal area of Lae

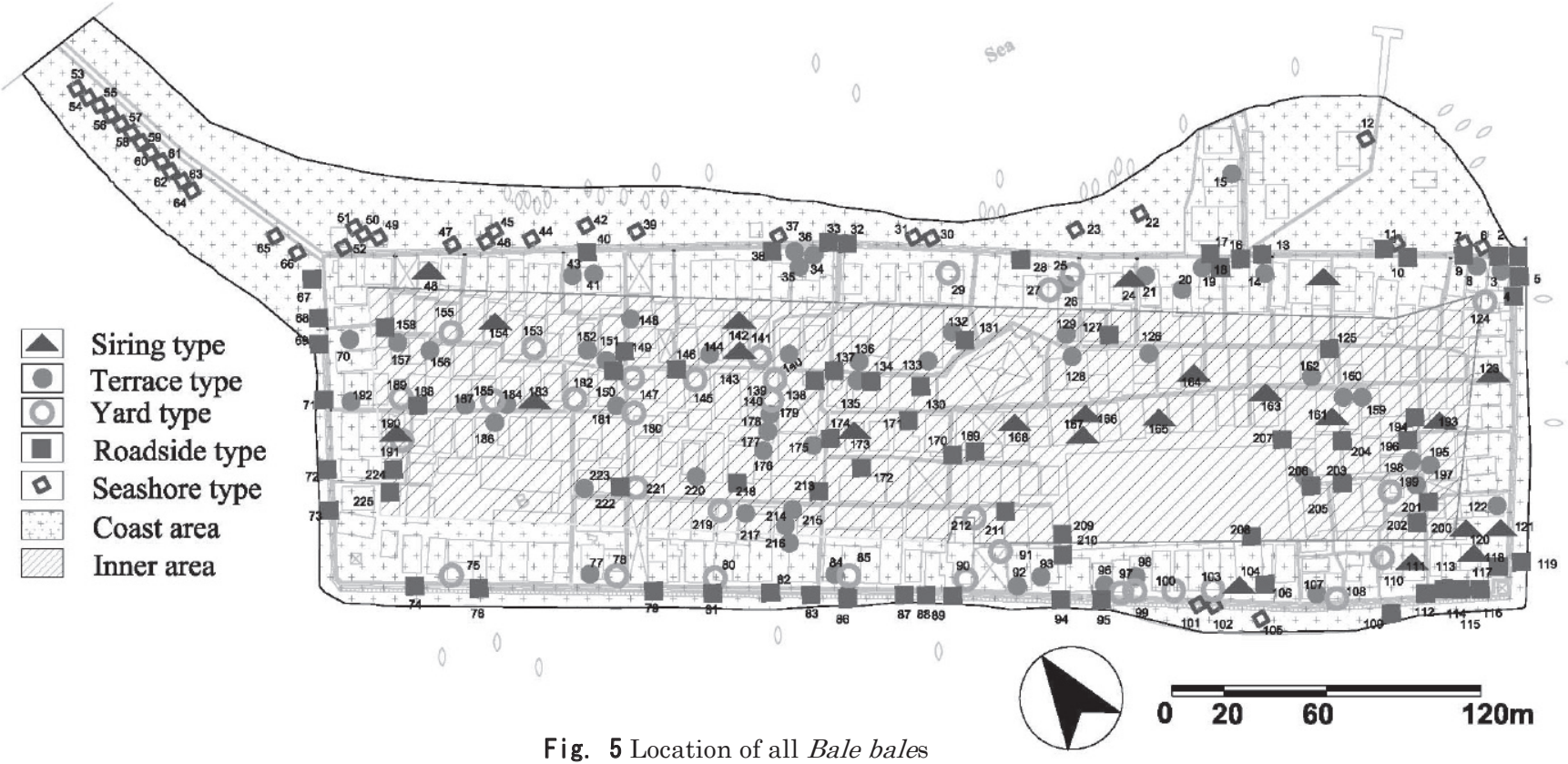


Lae isle. There are 35 seashore type of Bale bales (15.6\%), and most of them are placed in the northern part of the isle (91.4\%). Some of the Bale bales are built for renting and are placed at the breakwater.

Similar to the roadside type, the "Ss" type of Bale bale comes in the form of both a prototype and hut shape; it is made of both bamboo and wood or of wood only for its main structure and bamboo for its seat. The hut-shaped Bale bale incorporates a wall, backrest, and ladder for the convenience of its user.

\subsection{Form and Size of Bale bale}

Bale bale is a simple bench-like object, made of bamboo, wood, or a combination of the two materials where wood is used for the main structure and bamboo is used for the seating.

The form of Bale bale is divided into two types, namely, the prototype form (81.8\%) and the hut-shaped form (18.2\%), as depicted in fig. 6 . Several forms have been developed such as the hut-shaped Bale bale with wall, backrest, and ladder for the convenience of the user sitting on the Bale bale (fig. 7). Most prototypes of the Bale bale are of the Siring, Terrace, Yard, and Roadside types. The hut-shaped form is mostly of the seashore type.

Further, Bale bales are of many sizes, ranging from small to large. The average size of the siring Bale bale is $188 \times 124 \times 55$ $\mathrm{cm}$; the terrace type is $179 \times 118 \times 53 \mathrm{~cm}$; the yard type is $183 \mathrm{x}$ $132 \times 57 \mathrm{~cm}$. The prototype of the roadside Bale bale is $182 \times 141$ x $53 \mathrm{~cm}$; on the other hand, the hut-shaped Bale bale is large with an average size of $217 \times 173 \times 61 \mathrm{~cm}$. The average size of the prototype Bale bale of the seashore type is $199 \times 162 \times 61 \mathrm{~cm}$; on the other hand, the size of the hut-shaped Bale bale is an average of $230 \times 191 \times 61 \mathrm{~cm}$. The roadside and seashore Bale

Hut-shaped Bale bale (41/225)

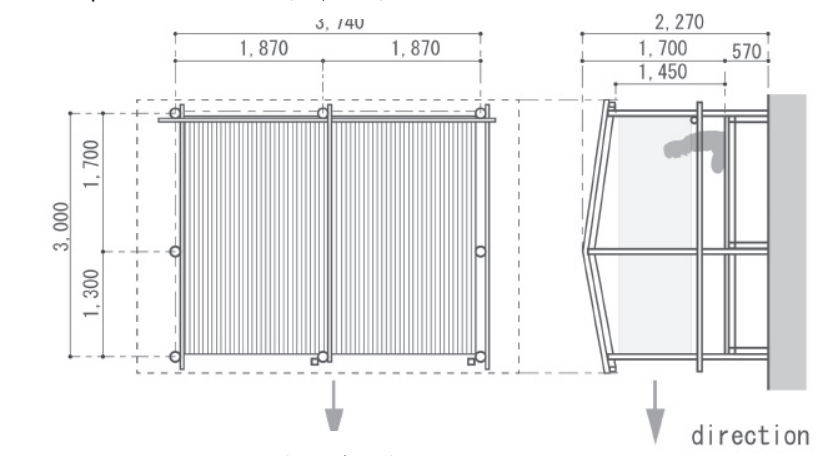

Prototype Bale bale (184/225)

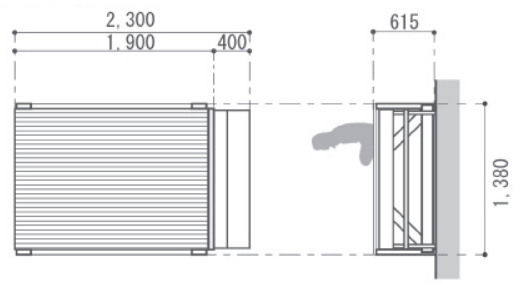

Fig. 6 Form of Bale bale

all direction

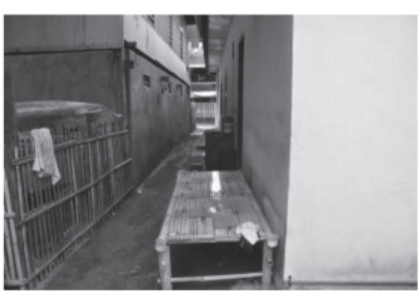

Prototype of Bale bale

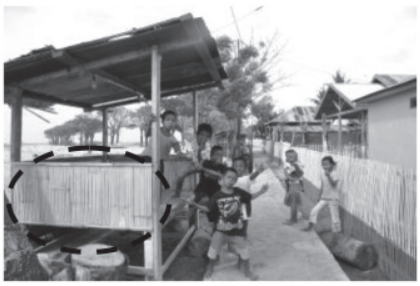

Bale bale hut-shaped with wall

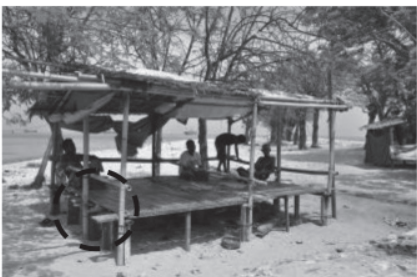

Hut-shaped Bale bale with backrest

Fig. 7 Prototype and forms of hut-shaped of Bale bale

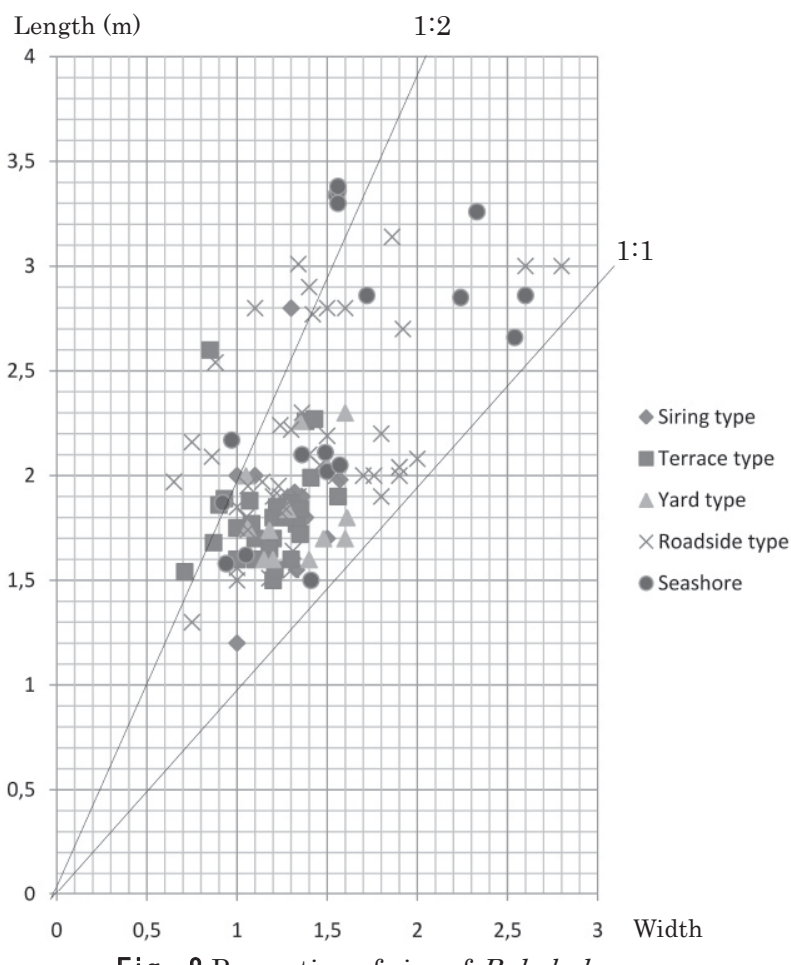

Fig. 8 Proportion of size of Bale bale

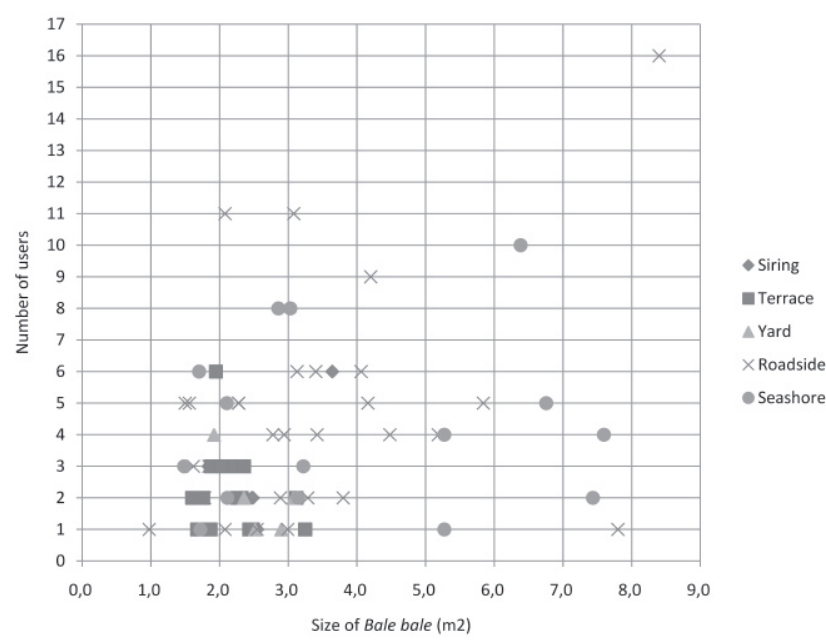

Fig. 9 Number of users on Bale bale 
bales are large, whereas almost all siring, terrace, and yard Bale bales are small (fig. 8).

The Bale bale tends to be square in form and bigger than other benches. For example, the "Endai", a bench, is located in front of the Japanese house. It is slim because it is used by Japanese people only for sitting. This differs from the Bale bale, which is used by the Lae lae islanders as a place to conduct various activities, either alone or with other people. The proportion of size of bale bale is between $1: 1$ to $1: 2$.

The number of users on Bale bale is not influenced by size of bale bale (fig. 9). Siring, terrace, and yard have a small size, and few of islander used it, but we find that roadside type with small size but many islanders used it. Only roadside of bale bale has variety of size and group of number of users, not only in family, but also others islanders.

\subsection{Layout of Bale bale}

The layout of a Bale bale is influenced by the direction of the Bale bale and the direction of the user's view (fig. 10)

\subsubsection{Siring type}

These types of Bale bale have four layouts: (1) one is placed in the $R P$ 's second row, (2) another is adjacent to the house wall in the $R P$ ' first row, (3) the third is in the $R P$ 's second row, and (4) the fourth is adjacent to the terrace wall in the $R P \mathrm{~s}$ first row. The Bale bale has two locations, namely, at the center of the siring and adjacent to the wall of a house. This allows users to view all directions: looking outside to the street, looking inside the house, and to the sides.

\subsubsection{Terrace type}

The "T" type of Bale bale has only one direction because one side of it is adjacent to the house or terrace wall and the fence; however, those sitting can see in many directions. The layout of this type is (1) adjacent to the terrace wall, (2) adjacent to the fence, (3) adjacent to the house's wall, (4) adjacent to the side of the house's wall, and (5) two Bale bales adjacent to the house wall. Users can look directly into the house and toward the side of the house, if one side of the Bale bale is adjacent to the terrace wall and fence. Conversely, users can look outside the house (toward the street) and toward the side of the house if one side of the Bale bale is adjacent to the house's wall. With the Bale bale that is located on the left or right side of the terrace and adjacent to the wall, users can look directly toward the house's side and outside (to the street).

\subsubsection{Yard type}

This type of Bale bale has only one direction because one side of it is adjacent to the house wall, terrace wall, or fence. It has six layouts: (1) adjacent to the terrace wall, (2) under a tree, (3) inside the hut, (4) adjacent to the house wall, (5) between two houses, and (6) at the right or left side of the house. All Bale bales have only one direction because one side of the Bale bale is adjacent to the wall or fence. Users can see in all directions from the first, second, and fifth layouts; they can look forward, sideways, and backward. In the third layout, the user can see in only one direction because the view is obstructed by the hut wall. Meanwhile, in the fourth and sixth layout, users can see in three directions: looking outside or inside from the house and toward the sides.

\subsubsection{Roadside type}

The roadside type comprises two forms, namely, the prototype of Bale bale (77.9\%) and the hut-shaped Bale bale (22.1\%). The direction of the "R" Bale bale is determined by its form; the prototype of the Bale bale has two directions: two ways (toward the sea and toward the street) and one way (toward the street). The hut-shaped Bale bale has three directions: toward the settlement (house), toward the street, and toward the sea. Bale bales in public spaces have four layouts: (1) across the street, (2) adjacent to the fence, (3) in the alley, and (4), in the case of the hut-shaped Bale bale, facing toward the settlement. The user of the prototype Bale bale can see in all directions because no wall or tree prevents his or her view. Whereas, users of the hut-shaped Bale bale can look in front and toward the side, but they cannot look back to the sea because the wall of the hut-shaped Bale bale obstructed their view.

\subsubsection{Seashore type}

The direction of Bale bale "Ss" type has two directions: toward the sea (sunset and Makassar city view), toward the settlement (house). The prototype form of the "Ss" bale bale has the both directions. The "Ss" Bale bale type comprises five layouts: (1) On the coast and facing the beach, (2) under the tree, (3) facing toward the settlement, (4) at the breakwater, and (5) facing the direction of the street. Almost all of these types of Bale bales allow users to see in three directions, because the hut shape with a back wall obstructs users' view; whereas with the prototype Bale bale users can see in all directions because nothing prevents their view.

\subsection{Users of Bale bale}

Observations made at three different times show that men, women, children (male), children (female), and babies use the Bale bale for their activities (fig. 11). Women and men most often gather in the afternoon (15:00-17:00); on the other hand, children, both male and female often gather in the morning (10:00-12:00). Men usually rest after catching fish and women rest after they finish preparing lunch and dinner for their 


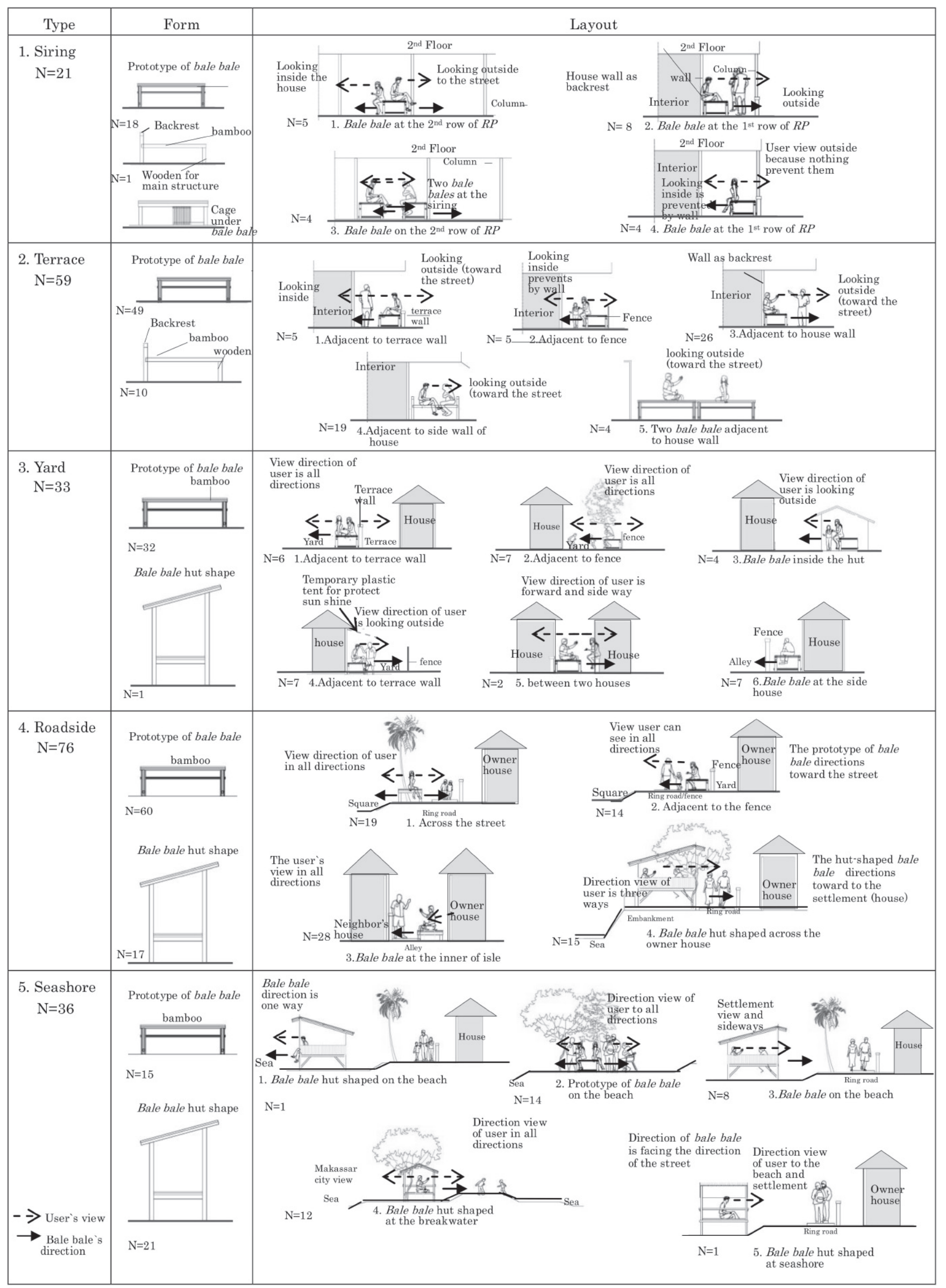

Fig. 10 Layout of Bale bale 


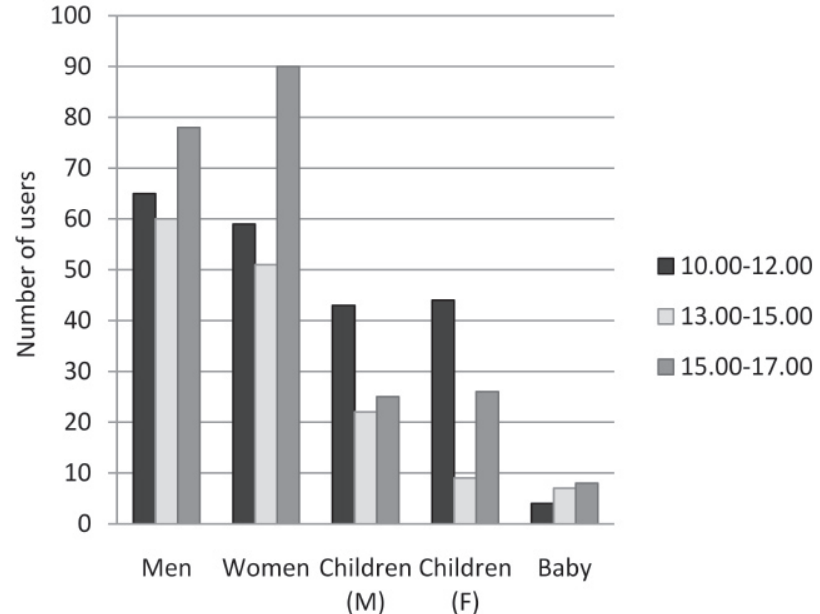

Fig. 11 Diagram of user activity by generation

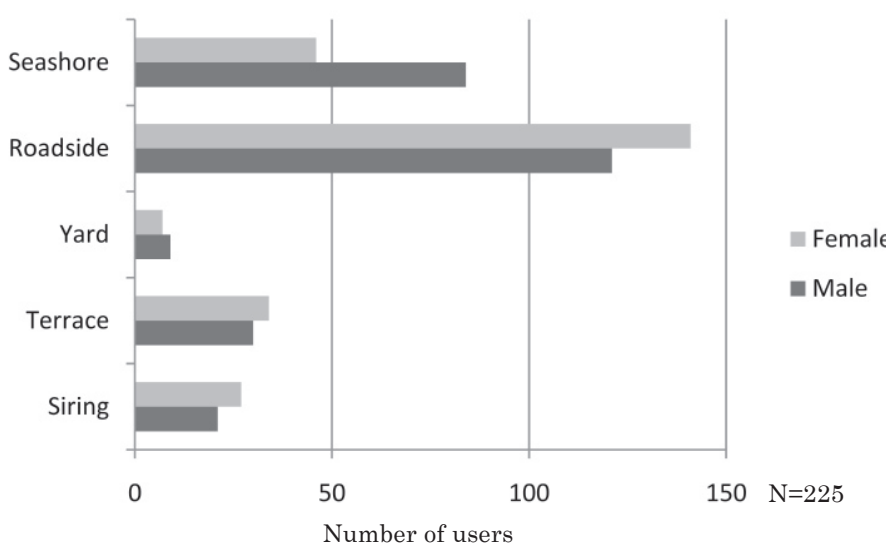

Fig. 12 User by gender on each type of Bale bale

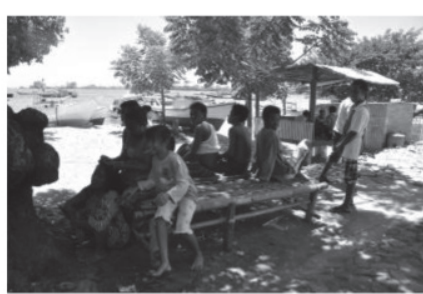

Sitting

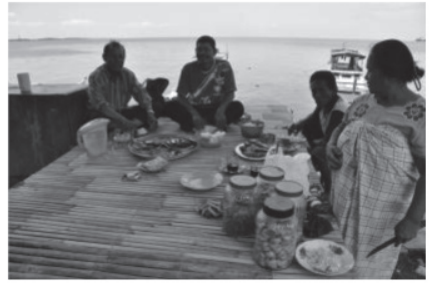

Eating

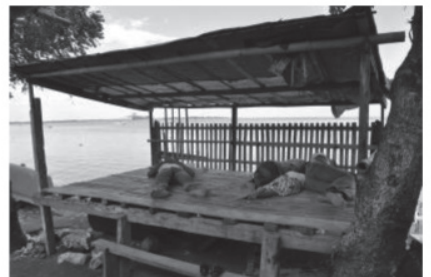

Sleeping

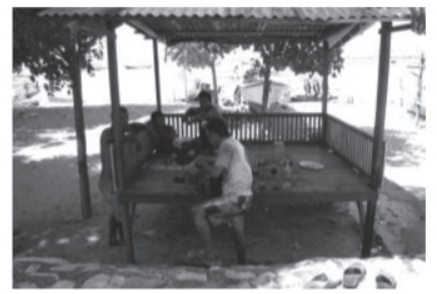

Working
Fig. 13 Activities on Bale bales

families. For children, the time for gathering or playing is almost the same among males and females.

The seashore Bale bale is more frequently used by males than females, whereas roadside Bale bale is more frequently used by females than males. Further, the siring, terrace, and yard bale bale are frequently used by females and males (fig 12).

\subsection{Activities on Bale bale}

The field surveys reveal that there are many activities conducted by the islanders on the Bale bale, such as chatting, sleeping, eating, working, etc. (fig. 13). The roadside Bale bale is used for a variety of activities such as sitting, chatting, sleeping, eating, lying down, working, etc. (fig. 14). This is because many "R" Bale bales are scattered on this isle and are easily accessible by everyone. In addition, the users sitting on the Bale bale feel comfortable because of the fresh air and many trees that protect them from the sun. Similar to the roadside Bale bale, the seashore Bale bale is used to perform many activities because it is placed in public spaces and is easily accessible by people. The terrace Bale bale is more common than the seashore one, but is used less often and for fewer activities than the seashore Bale bale. This is because the seashore type is more easily accessible by people as compared to the terrace type, which is placed on the house owner's terrace

The siring Bale bale, although small in size, is used for a variety activities and more frequently than the yard bale bale. This is because siring Bale bales are shielded from sunlight so that users feel comfortable using them.

In general, sitting and chatting are the most frequent activities performed by islanders on Bale bales. Sleeping, eating, lying down to rest, and repairing boat engines are mostly done by Lae Lae islanders on roadside and seashore Bale bales because Bale bales are located in front of the owner's house and in the public spaces, so it is easily accessible for use by the owner and everyone else. protects users from the sun. On the other hand, activities such as making fishing gear (nets), sewing, and folding of laundry are mostly done on siring and terrace Bale bales.

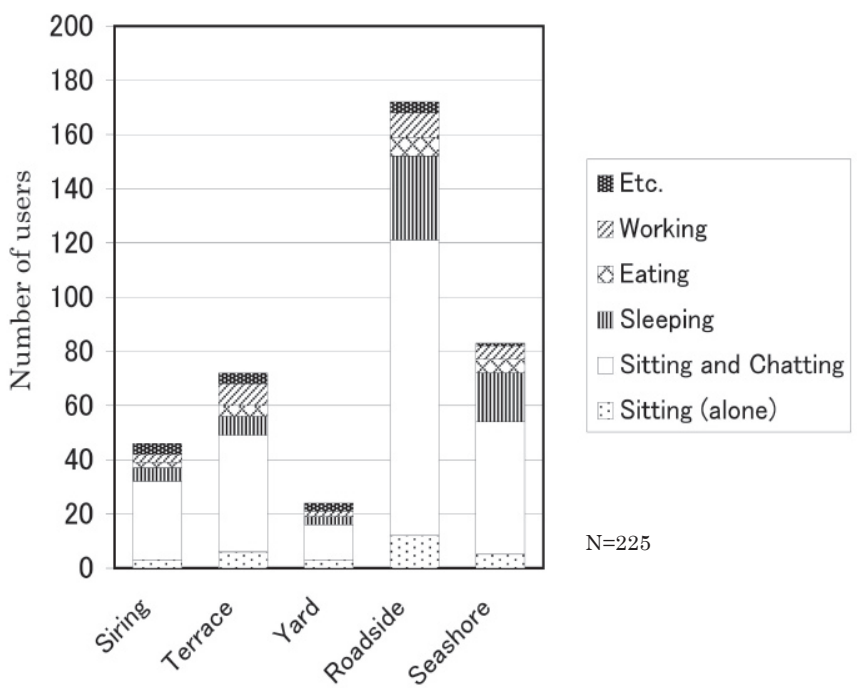

Type of Bale bale

Fig. 14 Activities of the users 


\section{Conclusions}

The Bale bale is not merely a simple bench made of bamboo or wood or a combination of the two, but is a common space the islanders of Lae Lae use in their daily lives and activities. The main findings of this study are described in the following manner:

First, the islanders can put their Bale bale anywhere on Lae Lae isle because there are no rules governing the placement of Bale bales in public spaces, except for the hut-shaped ones, for which the owner must notify the head of the ward of Lae Lae. Owners can move their Bale bale from one place to another, including the neighbors without permission.

Second, the Bale bale is classified into five types, namely, siring terrace, yard, roadside, and seashore. The roadside and seashore type are commonly found scattered along the ring road and the majority are located in the coastal area, in front of owners' houses. Whereas siring, terrace, and roadside Bale bales are located around owners' houses or inside the fence.

Third, the Bale bale has a variety of sizes and two forms, namely, prototype Bale bale and the hut-shaped Bale bale. The hut-shaped type has walls, a backrest, and ladder. The prototype Bale bale is mostly of the siring, terrace, yard, and roadside types, whereas the hut-shaped Bale bale is mostly of the seashore type. The roadside and seashore Bale bales are large, whereas almost all siring, terrace, and yard Bale bales are small. The Bale bale tends to be square in form (1:1 to 1:2). The number of users on Bale bale is not influenced by size of bale bale

Fourth, each type of Bale bale has many layouts, which influences the direction of the Bale bale and its users' view. The direction of the prototype Bale bale, whether siring, terrace, or yard type, are two ways. The user can look outside toward the street, inside toward the house, and toward the house's side. The direction of the hut-shaped Bale bale is one way, toward the house, street, or sea. The user can look in front and toward the side.

Fifth, the roadside Bale bale is more frequently used than the others type. The females often gather on Bale bales in the afternoon and the males in the morning and in the early afternoon. Females often use Bale bales that are close to their houses, such as the siring, terrace, yard, and roadside Bale bales, whereas the seashore Bale bale, which is far from the house, is often used by males. Bale bale owners and islanders of Lae Lae perform many activities on the Bale bale, but the main activity is sitting and chatting. The roadside and seashore types are mostly used by islanders for sleeping, eating, lying down, and repairing their boat machines. However, making fishing gear (nets), sewing, and folding of laundry are mostly done on siring and terrace Bale bales.

\section{Acknowledgment}

The present study is supported by the Ministry of the Directorate General Higher Education Department of National Education Indonesia.

\section{Notes}

(i) Bale bales can be found everywhere in Indonesia, such as in Bali (called tabang and bale bengong), in Jawa (called risban and Bale bale), and in Sumatera (called palanta, moa).

(ii) Rumah Panggung (house on stilts) is a traditional form of Makassarese/Buginese architecture. It is divided into three parts: a top floor for storage, a middle floor for daily living, and a bottom floor (called Siring) for multipurpose activity, including the creation of a place for Bale bale.

(iii) Siring is a space which is located at underneath of rumah panggung

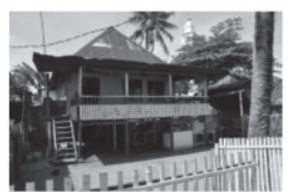
(house on stilts). It is use for multiuse, such as for storage, cage, including for Bale bale place. Also, this place is develop for guest room, bedroom, kitchen, toilet, and living room.

\section{References}

1) Byun, K., Fukushima, S., Hirate, K.: A Study on the Planning and Use of Common Space in Private Rental Apartments in Okinawa, Japan. Journal of Asian Architecture and Building Engineering, Vol. 7 No. 1 pp 47-54, 2008.

2) Central Board Statistic of Makassar: Makassar in Figure. Pemerintah Kota Makassar, 2010

3) Cho, P., Sawaki., M.: Study on the Neighborhood Characteristic of High-Density Hillside Areas through Common Space; A Case Study on an On-the spot Improvement Program District of the Housing Environment Amelioration Program in Busan, Korea. Journal of Asian Architecture and Building Engineering, Vol. 6 No. 1 pp 111-118, 2007.

4) Departemen Pendidikan Nasional: Indonesian Dictionary. Jakarta.Indonesia, 2008.

5) Gehl, J.: Life between Buildings; Using Public Space. New York. Van Nostrand Reinhold, 1987.

6) Kamihogi,A. at al.: Study on the Role of Common Space in Low-Rise Exclusive Residential Areas in Creating Community. Journa Sci Rep Coll Agric Osaka Prefect Univ., 2000.

7) Kanazawa, S., Jun, C.: Comparative Study on residents` Perception and Activities in Their Outdoor Spaces, Cases of Traditional Blocks and a New Housing Project in Beijing. Journal of Asian Architecture and Building Engineering, Vol. 1 No. 1 pp 221-228, 2002.

8) Kubota, K., Kurono,H.: Publicness of Gangi Street Supported by Use and Spatial Compisition. Proceedings of Architectural Institute of Japan Hokuriku branch (45) pp 299-302. In Japanese, 2002.

9) Noguchi, T., Tsukidate, E.: Form, Use and Clearing of Snow from the Gangi in Winter; Study on the Common Space Design of Public Apartment Houses in Heavy Snowfall Areas in Japan. Journal of Asian Architecture and Building Engineering, Vol. 1 No. 1 pp 245-251, 2002.

10) Suzuki, Takeshi: Mode of Being in Places: A Case Study in Urban Public Space, in Handbook of Japan-United States Environment-Behavior Research: Toward a Transactional Approach, edited by Seymour Wapner, Jack Demick, Takiji Yamamoto, and Takashi Takahashi. New York. Plenum Press, 1997. 


\section{和文要約}

本稿はインドネシア, 南スラウェシの州都マカッサル市の沖合に あるラエラエ島における縁台的なしつらえバレバレ（Bale Bale） に関する研究報告である。この種の屋外家具はアジア各国に存在 しているが，面積わずか 0.22 km²，住民約 1550 人の小島であるラ エラエ島には，225 のバレバレがあり島民の重要な生活の場とな っている。フィールドワーク及びアンケート・インタビュー調査 から以下のことが明らかになった。

1 ) バレバレは住民が自由に設置でき家族のみならず島民や訪問 者の誰でも利用することができる（自分の住居敷地内もしくはそ の近傍に設置する場合が多い。屋根のあるタイプについては許可 が必要)。

2 ) バレバレは設置場所によって，5つのタイプ，すなわち，伝 統的住居の床下 Siring, テラス Terrace, ヤード yard, 道端 roadside, 浜辺 seashore に分けることができ, 道端タイプが最
も数が多い。

3 ) その形態はベンチ的プロトタイプから屋根や壁のあるものま で様々であり, 平面寸法は概ね $1.5 \mathrm{~m} \times 2 \mathrm{~m}$ 程度だが, 道端・海辺 タイプには $3 \mathrm{~m}$ 以上のものある。平面のプロポーションは $1: 1$ と 1:2の間で一般的な日本の縁台よりずんぐりしている。同時に利 用する人数は 1 人一 16 人と幅広く, 面積とは明解な相関はない。

4 ）設置場所（たとえば塀に沿って）や形態（屋根や壁）によっ て方向性があるバレバレも多く, その向きとしては街路が最も重 視され，海だけを向くバレバレはごく少数で例外的である。

5 ) バレバレは主に, 休㮩, 会話, 昼寝, 食事, 作業などに使用 される。最もよく利用されるのは道端タイプと浜辺タイプである。 利用時間やタイプについて男性・女性で若干の違いがあり, 浜辺 タイプは男性の利用がやや多い。

(2011年 7 月 10 日原稿受理，2012年 1 月25日採用決定） 